636

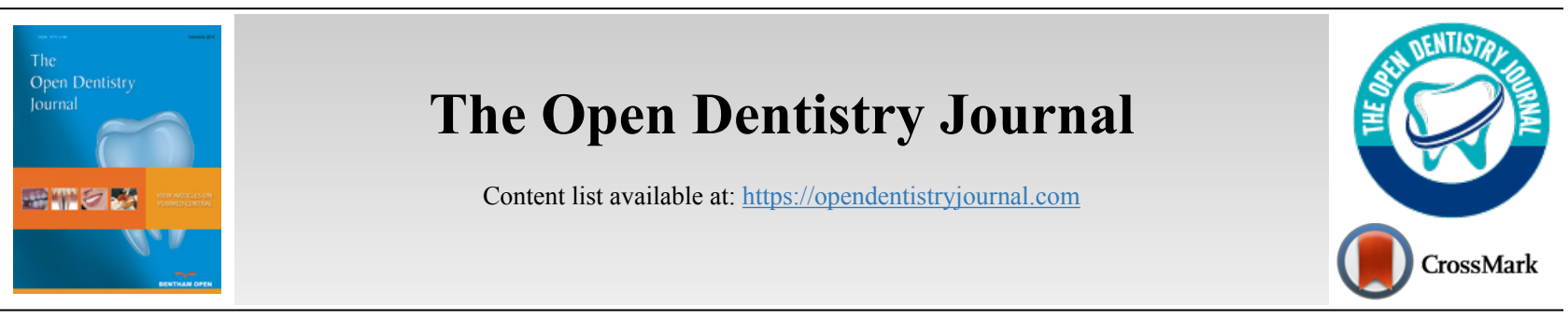

RESEARCH ARTICLE

\title{
Evaluating the Knowledge of General Dentist Towards the Management of Peri- Implant Diseases: A Multi-Center, Cross-Sectional Study
}

\author{
Ali R. Alqahtani ${ }^{1}$, Khalid Gufran ${ }^{2, *}$, Abdulaziz M. Alqahtani ${ }^{3}$, Faisal N. Alazemi ${ }^{3}$ and Khaled M. Alzahrani ${ }^{4}$ \\ ${ }^{\prime}$ Department of Conservative Dental Sciences, College of Dentistry, Prince Sattam Bin Abdulaziz University Alkharj, Alkharj, Saudi Arabia \\ ${ }^{2}$ Department of Preventive Dental Sciences College of Dentistry, Prince Sattam Bin Abdulaziz University Alkharj, Alkharj, Saudi Arabia \\ ${ }^{3}$ BDS, General Practitioner, Riyadh, Saudi Arabia \\ ${ }^{4}$ Department of Prosthetic Dental Sciences College of Dentistry, Prince Sattam Bin Abdulaziz University Alkharj, Alkharj, Saudi Arabia
}

\begin{abstract}
:
Background:

Recently, implants have been widely considered as an option for replacing missing teeth. There are several biological conditions that must be considered for the success of an implant. Failure to satisfy any of these factors may result in complications, such as peri-implantitis or failure of the implant.

Aim:

The aim of this study was to evaluate the general dentist's attitude towards the management of peri-implant diseases in Saudi Arabia.

Methods:

A multicenter cross-sectional electronic-based questionnaire was formulated based on the validated questionnaire from a previous study. It was targeted towards the general dental practitioners in Saudi Arabia. The study sample consisted of 721 general dental practitioners. The questionnaire consisted of 17 questions divided into five sections. Pearson's chi-square test was used for inferential statistical analysis with Holm's correction, for adjusted p-value, the alpha at $95 \%$ confidence interval was 0.05 , and all values below alpha were considered statistically significant.

Results:

The majority of participants had attended an implant training course (51.2\%) while the rest had not (48.7\%). The majority of the participants $(67.3 \%)$ thought they need special instruments for the detection of peri-implantitis but only $29.5 \%$ thought they do not need any special instruments for the intended purpose. Most participants (79.3\%) said they can identify and differentiate between normal and abnormal soft tissue around an implant, while $6.5 \%$ of the respondents could not. More than half of the participants $(54.8 \%)$ could differentiate between peri-implant mucositis and peri-implantitis, and $19.4 \%$ had no idea about this. Amoxicillin \& metronidazole was considered as the best and most effective antibiotic by the majority of respondents $(76 \%)$, while only $(5 \%)$ of dentists selected ciprofloxacin.

\section{Conclusion:}

This study concludes by suggesting that most of the participants have adequate knowledge about peri-implant soft tissue assessment, mechanism of periodontitis and peri-implantitis, its initiation and progression along with its management. Most of the participants found the training courses on peri-implantitis to be efficient. It is recommended to conduct more courses and studies that would aim at understanding the pathogenesis, etiology, diagnosis, and treatment of peri-implant diseases so as to increase awareness among general dentists.
\end{abstract}

Keywords: Peri-implant mucositis, Peri-implantitis, General dentist, Titanium, Amoxicillin, Metronidazole.

Article History

Received: February 21, 2021

Revised: July 30, 2021

Accepted: August 20, 2021

\section{INTRODUCTION}

Recently, implants are being widely considered as an option for replacing missing teeth. There are several biological

\footnotetext{
* Address correspondence to this author at the Department of Preventive Dental Sciences, College of Dentistry, Prince Sattam Bin Abdulaziz University, Alkharj, P.O Box 153, Postal code 11942, Saudi Arabia; Tel: 00966502294308; E-mail: khalidg08@gmail.com
}

conditions that must be considered for the success of an implant. Failure to satisfy any of these factors may result in complications, such as peri-implantitis or failure of the implant [1].

Peri-implant diseases are inflammatory diseases of the surrounding implant tissues categorized into peri-implant mucositis and peri-implantitis. In peri-implantitis, the lesion 
presents progressive peri-implant bone loss beyond the initial physiologic bone remodeling that occurred following implant placement. In peri-implant mucositis, the lesion is limited to the peri-implant soft tissues and is diagnosed by the presence of bleeding on probing [2].

According to a study, the prevalence of peri-implantitis is one in four patients and of peri-implant mucositis is two in five patients. A recent meta-analysis on the epidemiology of periimplant diseases conducted by Jepsen et al. during the $11^{\text {th }}$ European workshop on periodontology shows the mean prevalence of $22 \%$ for peri-implantitis and $43 \%$ for periimplant mucositis [2].

Radiographs also are helpful in appreciating the extent of peri-implantitis. Along with the absence of peri-implant radiolucency, a mean Marginal Bone Loss (MBL) ranging from $0.9 \mathrm{~mm}$ to $1.6 \mathrm{~mm}$ throughout the first postsurgical year was established as a benchmark for implant success. A mean annual MBL ranging from 0.05 to $0.13 \mathrm{~mm}$ at the maintenance phase was recognized as another criterion for implant success $[3,4]$. There is also a lack of association between overload and peri-implant tissue loss in healthy conditions [5].

Management of peri-implantitis is done by the following methods, either individually or in combination. They include local debridement, surface decontamination of the implant, raising a surgical flap for cleaning and decontamination of the implant while trying to maintain and conserve the surrounding soft tissues and antimicrobial drugs. In case of retrograde periimplantitis, treatment options like surgical debridement of the apical part of the implant with/without the application of a bone substitute/Guided Bone Regeneration (GBR) procedure and the possible resection of the apical part of the dental implant are advocated [6, 7].

It should be noted, however, that the local debridement of the implant should be done by instruments softer than titanium, such as: polishing paste with a rubber cup, interdental floss / brushes, or by using plastic scaling instruments [8].

There is very little available information regarding the attitude of a general dentist's towards the protocols used for the management of peri-implantitis. Therefore, the aim of this study was to evaluate the general dentist's attitude towards the management of per-implantitis diseases in Saudi Arabia.

\section{MATERIALS AND METHODS}

\subsection{Study Design}

A multicenter cross sectional electronic based questionnaire was formulated based on the validated questionnaire from a previous study [9]. It was targeted towards the general dental practitioners in Saudi Arabia. The questionnaire was circulated from $3^{\text {rd }}$ April until $25^{\text {th }}$ May 2020.

The questionnaire consisted of 17 questions in total which were divided into 5 sections. The first section was about the demographic data such as the patient's age, gender, education level and clinical experience. The second section consisted of questions regarding the implant therapy training, while the third section was about the soft tissue assessment for periimplant. The fourth section dealt with peri-implant diseases. In this section, questions were aimed at evaluating the general dentist's knowledge of the mechanism of periodontitis and peri-implantitis and about the progression of the disease. The fifth and the last parts of the questionnaire were regarding the treatment plan of peri-implant diseases.

\subsection{Ethical approval}

The ethical clearance for the study was obtained from the ethical committee of the College of Dentistry, Prince Sattam Bin Abdulaziz University in Alkharj province, Riyadh, Saudi Arabia (IRB/PSAU2020017). All the subjects of the study took part voluntarily, and their anonymity was ensured. All the data collected were treated confidentially.

\subsection{Data Collection}

The study sample consisted of 721 general dental practitioners in Saudi Arabia, which included both male and female dentists. The exclusion criteria included all consultants, specialists or undergraduate students. The survey was constructed using survey monkey and distributed to the doctors via emails and social media. Emails were also sent via the Saudi Commission For Health Specialities (SCFHS) to all the registered General Practitioner dentists (GP) in Saudi Arabia. The questionnaire was prepared in English with clear instructions explaining the nature and the objectives of the study. Before distributing the questionnaire, a pilot study was initially conducted on 5 randomly selected general dentists to evaluate the understanding of the questions, choices and also to calculate the time needed to complete the study. It was concluded that there were no issues encountered with the pilot study and the time taken was around 3-4 minutes.

\subsection{Statistical Analysis}

The collected data was analyzed using Statistical Package for Social Sciences (SPSS, IBM, v. 21). Frequency distribution of demographic variables and participant responses to individual questions were calculated. Pearson's chi-square test was used for inferential statistical analysis with Holm's correction for adjusted p-value; the alpha at $95 \%$ confidence interval was 0.05 and all values below alpha were considered statistically significant.

\section{RESULTS}

A total of 721 subjects participated in this study. Participants were almost equally distributed as males and females with slightly more males $(51.3 \%)$ than females $(48.4 \%)$, and most of the participants had 1-5 years of experience: $(71.7 \%)$. Table 1 depicts the demographic information of participants. The majority of the participants were $24-30$ years old $(73.1 \%)$ and the least number of participants were above 40 years of age (7.6\%).

Table 2 depicts the frequency distribution of participant's responses to individual questions. The majority had attended an implant training course (51.2\%) while the rest had not (48.7\%). Out of those who attended a training course, $26.1 \%$ said it was a short training course, $25.4 \%$ said it was provided by an academic organization, while the rest were trained by commercial courses or moderate training courses. Some of 
them $(38 \%)$ did not take any training courses. Most participants (51.2\%) agreed on the optimal efficacy of the training courses on peri-implantitis while (13.9\%) disagreed. Some of the participants $(13.5 \%)$ did not have an opinion on this. The majority of the participants $(67.3 \%)$ thought they needed special instruments for the detection of peri-implantitis, but only $29.5 \%$ thought they do not need any special instruments for the intended purpose. When asked about the instrument usually used for measurement of probing depth of periimplantitis, most participants answered plastic probes (182, $25.2 \%$ ), and the instrument least chosen was a titanium curette $(3.7 \%)$. However, $37.2 \%$ of people thought the plastic curette was an ideal instrument for scaling the implant surface. Some of the participants $(29.1 \%)$ had no idea about the ideal instrument for scaling and very few $(4.6 \%)$ selected the stainless-steel curette.

Table 1. Demographic information of participants.

\begin{tabular}{|c|c|c|}
\hline Demographics & Frequency $(\mathrm{N}=721)$ & Percentage (\%) \\
\hline \multicolumn{3}{|l|}{ Age } \\
\hline $24-30$ & 527 & 73.1 \\
\hline $31-40$ & 137 & 19 \\
\hline$>40$ & 55 & 7.6 \\
\hline N/A & 2 & 0.3 \\
\hline \multicolumn{3}{|l|}{ Gender } \\
\hline Male & 370 & 51.3 \\
\hline Female & 349 & 48.4 \\
\hline N/A & 2 & 0.3 \\
\hline \multicolumn{3}{|c|}{ Clinical Experience } \\
\hline $1-5$ years & 517 & 71.7 \\
\hline $5-10$ years & 97 & 13.5 \\
\hline$>10$ years & 63 & 8.7 \\
\hline$>20$ years & 42 & 5.8 \\
\hline N/A & 2 & 0.3 \\
\hline
\end{tabular}

Table 2. Frequency distribution of participant responses to individual questions.

\begin{tabular}{|c|c|c|}
\hline Questions & Frequency $(\mathrm{N}=721)$ & Percentage (\%) \\
\hline \multicolumn{3}{|l|}{ Have you attended any implant training course? } \\
\hline Yes & 369 & 51.2 \\
\hline No & 351 & 48.7 \\
\hline N/A & 1 & 0.1 \\
\hline \multicolumn{3}{|l|}{ Training course provider: } \\
\hline Short training course & 188 & 26.1 \\
\hline Academic organization & 183 & 25.4 \\
\hline Commercial courses & 42 & 5.8 \\
\hline Moderate training course & 34 & 4.7 \\
\hline $\mathrm{N} / \mathrm{A}$ & 274 & 38 \\
\hline \multicolumn{3}{|c|}{ Optimal efficacy of the training courses on peri-implantitis? } \\
\hline Agree & 369 & 51.2 \\
\hline Strongly agree & 155 & 21.5 \\
\hline Disagree & 100 & 13.9 \\
\hline $\mathrm{N} / \mathrm{A}$ & 97 & 13.5 \\
\hline \multicolumn{3}{|c|}{ Do you think you need special instrument for detection of peri-implantitis? } \\
\hline $\begin{array}{c}\text { Yes } \\
\end{array}$ & 485 & 67.3 \\
\hline No & 213 & 29.5 \\
\hline N/A & 23 & 3.2 \\
\hline \multicolumn{3}{|c|}{ Which Instrument do you use for measuring (probing depth) instrumentation of peri-implantitis? } \\
\hline Plastic probe-Implant cleaning brush & 28 & 3.9 \\
\hline Plastic probe & 182 & 25.2 \\
\hline Plastic probe- Stainless steel probe & 102 & 14.1 \\
\hline Plastic probe-Titanium curette & 87 & 12.1 \\
\hline
\end{tabular}


(Table 2) contd.....

\begin{tabular}{|c|c|c|}
\hline Questions & Frequency $(\mathrm{N}=721)$ & Percentage (\%) \\
\hline Plastic probe- Plastic curette & 78 & 10.8 \\
\hline Stainless steel probe & 171 & 23.7 \\
\hline Titanium curette & 27 & 3.7 \\
\hline Plastic probe-Diluted hydrogen peroxide & 15 & 2.1 \\
\hline N/A & 31 & 4.3 \\
\hline \multicolumn{3}{|c|}{ What's the ideal instrument for instrumentation (scaling) the implant surface? } \\
\hline Plastic curette & 268 & 37.2 \\
\hline No idea & 210 & 29.1 \\
\hline Titaniumcurette & 124 & 17.2 \\
\hline No curette & 63 & 8.7 \\
\hline Stainless steel curette & 33 & 4.6 \\
\hline $\mathrm{N} / \mathrm{A}$ & 23 & 3.2 \\
\hline \multicolumn{3}{|c|}{ Can you differentiate between normal and abnormal soft tissue around implant? } \\
\hline Yes & 572 & 79.3 \\
\hline No idea & 83 & 11.5 \\
\hline No & 47 & 6.5 \\
\hline N/A & 19 & 2.6 \\
\hline \multicolumn{3}{|c|}{ Frequency of complications you have faced (failure/ inflammatory disease)? } \\
\hline Lessthan 5 per year & 508 & 70.5 \\
\hline $5-10$ per year & 118 & 16.4 \\
\hline 10-15 per year & 34 & 4.7 \\
\hline $\mathrm{N} / \mathrm{A}$ & 61 & 8.5 \\
\hline \multicolumn{3}{|c|}{ Can you differentiate between peri-implant mucositis from peri-implantitis? } \\
\hline Yes & 395 & 54.8 \\
\hline No idea & 140 & 19.4 \\
\hline No & 164 & 22.7 \\
\hline N/A & 22 & 3.1 \\
\hline \multicolumn{3}{|c|}{ Do you know the difference in initiating mechanisms of periodontitis and peri-implantitis? } \\
\hline Yes & 380 & 52.7 \\
\hline No & 176 & 24.4 \\
\hline No idea & 141 & 19.6 \\
\hline $\mathrm{N} / \mathrm{A}$ & 24 & 3.3 \\
\hline \multicolumn{3}{|c|}{ Do you know the difference in progression time of periodontitis and peri-implantitis? } \\
\hline No & 247 & 34.3 \\
\hline No idea & 156 & 21.6 \\
\hline Yes & 295 & 40.9 \\
\hline N/A & 23 & 3.2 \\
\hline \multicolumn{3}{|l|}{ Peri-implantitis classification(s) } \\
\hline Two & 142 & 19.7 \\
\hline Three & 387 & 53.7 \\
\hline One & 51 & 7.1 \\
\hline Morethan three & 106 & 14.7 \\
\hline $\mathrm{N} / \mathrm{A}$ & 35 & 4.9 \\
\hline \multicolumn{3}{|c|}{ Recall frequency for patients who received dental implants } \\
\hline Every 1-6 months in the first year & 321 & 44.5 \\
\hline Once a year & 76 & 10.5 \\
\hline Every $1-2$ months & 55 & 7.6 \\
\hline Every 3-4 months & 241 & 33.4 \\
\hline $\mathrm{N} / \mathrm{A}$ & 28 & 3.9 \\
\hline \multicolumn{3}{|c|}{ Which Antibiotic is most effective? (according to ADA) } \\
\hline Amoxicillin- Metronidazole & 548 & 76 \\
\hline Doxycycline & 71 & 9.8 \\
\hline Azithromycin & 43 & 6 \\
\hline Ciprofloxacin & 36 & 5 \\
\hline
\end{tabular}


(Table 2) contd.....

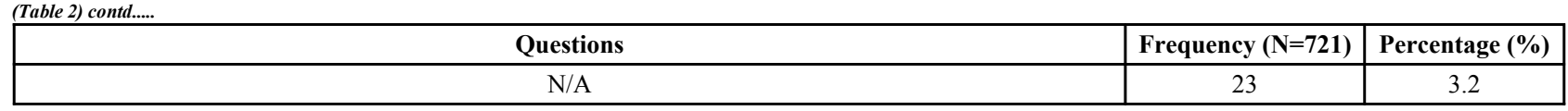

Most participants $(79.3 \%)$ said they can identify and differentiate between normal and abnormal soft tissue around an implant, while $6.5 \%$ of the respondents could not., The majority of the participants $(70.5 \%)$, claimed to face complications such as failures and inflammatory diseases less than 5 times per year, while others $(4.7 \%)$ said they face between 10 to 15 complications a year. More than half of the participants $(54.8 \%)$ can differentiate between peri-implant mucositis and peri-implantitis, and $19.4 \%$ had no idea about this matter. Additionally, $52.7 \%$ knew the difference in the initiating mechanisms of periodontitis and peri-implantitis, while $19.6 \%$ had no idea. Furthermore, $40.9 \%$ of the participants knew the difference in progression time of periodontitis and peri-implantitis, but a significant number $(34.3 \%)$ did not know this difference in progression. When asked about the classification(s) of peri-implantitis, the majority of the participants $(53.7 \%)$ responded that there are 3 classes, and $7.1 \%$ said that there is only one class. The appropriate recall frequency for patients who received dental implants was thought to be every 1-6 months after the first year according to the majority of the participants (44.5\%), every $1-2$ months as per $7.6 \%$ of the participants and no recalls according to $3.9 \%$ of the participants. Amoxicillin-metronidazole was considered as the best and most effective antibiotic by the majority of respondents $(76 \%)$, while only $(5 \%)$ of dentists selected ciprofloxacin.

Table 3 presents the results of the chi-square test that was done to determine whether any significant difference existed in the knowledge of participants with respect to age, gender and clinical experience. Whether or not participants had attended a training course (Q.4) differed statistically significantly among different age groups $(\mathrm{p}=0.003)$, between males and females $(\mathrm{p}=0.014)$ and between different years of clinical experience (0.009). When participants did attend a training course, the training course provider (Q.5) differed significantly with respect to age $(p=0.006)$ and clinical experience $(p<0.001)$. The knowledge of instrumentation for measuring probing depth (Q.8) also differed significantly with respect to age $(\mathrm{p}<0.001)$ whereas the knowledge of instrumentation for scaling the implant site (Q.9) differed significantly with age and gender $(\mathrm{p}<0.001$ for both). Similarly, knowledge of peri-implant classifications (Q.15) differed significantly with respect to age $(p=0.013)$ and gender $(p=0.007)$. Lastly, knowledge about progression time of periodontitis and peri-implantitis (Q.14) different significantly with respect to age only $(\mathrm{p}=0.045)$. There was no significant difference in responses to other questions with respect to any variable.

Table 3. Chi-square test comparing differences in responses of participants with respect to age, gender and clinical experience.

\begin{tabular}{|c|c|c|c|c|}
\hline- & Question & DemographicVariable & p-value & Adjusted p-value \\
\hline \multirow[t]{3}{*}{1} & \multirow[t]{3}{*}{ Have you attended any implant training course? } & Age & $<0.001$ & 0.003 \\
\hline & & Gender & $<0.001$ & 0.014 \\
\hline & & Clinical Experience & $<0.001$ & 0.009 \\
\hline \multirow[t]{3}{*}{2} & \multirow[t]{3}{*}{ Training course provider: (if Q4 answer was yes, answer this question) } & Age & $<0.001$ & 0.006 \\
\hline & & Gender & 0.305 & 1.000 \\
\hline & & Clinical Experience & $<0.001$ & $<0.001$ \\
\hline \multirow[t]{3}{*}{3} & \multirow[t]{3}{*}{ Optimal efficacy of the training courses on peri-implantitis? } & Age & 0.007 & 0.196 \\
\hline & & Gender & 0.713 & 1.000 \\
\hline & & Clinical Experience & 0.010 & 0.257 \\
\hline \multirow[t]{3}{*}{4} & \multirow[t]{3}{*}{ Do you think you need special instrument for detection of Peri-implantitis? } & Age & 0.040 & 0.876 \\
\hline & & Gender & 0.489 & 1.000 \\
\hline & & Clinical Experience & 0.146 & 1.000 \\
\hline \multirow[t]{3}{*}{5} & \multirow{3}{*}{$\begin{array}{l}\text { Which Instrument do you use for measuring (probing depth) Instrumentation of peri- } \\
\text { implantitis? }\end{array}$} & Age & $<0.001$ & $<0.001$ \\
\hline & & Gender & 0.775 & 1.000 \\
\hline & & Clinical Experience & $<0.001$ & $<0.001$ \\
\hline \multirow[t]{3}{*}{6} & \multirow[t]{3}{*}{ What's the ideal instrument for instrumentation (scaling) the implant surface? } & Age & $<0.001$ & $<0.001$ \\
\hline & & Gender & 0.114 & 1.000 \\
\hline & & Clinical Experience & $<0.001$ & $<0.001$ \\
\hline \multirow[t]{3}{*}{7} & \multirow[t]{3}{*}{ Can you differentiate between normal and abnormal soft tissue around implant? } & Age & 0.116 & 1.000 \\
\hline & & Gender & 0.372 & 1.000 \\
\hline & & Clinical Experience & 0.131 & 1.000 \\
\hline \multirow[t]{3}{*}{8} & \multirow[t]{3}{*}{ frequency of complications you have faced (failure/ inflammatory disease)? } & Age & 0.060 & 1.000 \\
\hline & & Gender & 0.257 & 1.000 \\
\hline & & Clinical Experience & 0.014 & 0.340 \\
\hline
\end{tabular}




\begin{tabular}{|c|c|c|c|c|}
\hline- & Question & DemographicVariable & p-value & Adjusted p-value \\
\hline 9 & \multirow[t]{3}{*}{ can you differentiate between peri-implant mucositis from peri-implantitis? } & Age & 0.073 & 1.000 \\
\hline & & Gender & 0.063 & 1.000 \\
\hline & & Clinical Experience & 0.142 & 1.000 \\
\hline \multirow[t]{3}{*}{10} & \multirow[t]{3}{*}{ Do you know the difference in initiating mechanisms of periodontitis and peri-implantitis? } & Age & 0.009 & 0.237 \\
\hline & & Gender & 0.595 & 1.000 \\
\hline & & Clinical Experience & 0.125 & 1.000 \\
\hline \multirow[t]{3}{*}{11} & \multirow[t]{3}{*}{ Do you know the difference in progression time of periodontitis and peri-implantitis? } & Age & 0.001 & 0.045 \\
\hline & & Gender & 0.140 & 1.000 \\
\hline & & Clinical Experience & 0.003 & 0.091 \\
\hline \multirow[t]{3}{*}{12} & \multirow[t]{3}{*}{ Peri-implantitis classification(s) } & Age & $<0.001$ & 0.013 \\
\hline & & Gender & 0.149 & 1.000 \\
\hline & & Clinical Experience & $<0.001$ & 0.007 \\
\hline \multirow[t]{3}{*}{13} & \multirow[t]{3}{*}{ Recall frequency for patients who received dental implants } & Age & 0.006 & 0.157 \\
\hline & & Gender & 0.795 & 1.000 \\
\hline & & Clinical Experience & 0.024 & 0.557 \\
\hline \multirow[t]{3}{*}{14} & \multirow[t]{3}{*}{ Which Antibiotic is most effective (According to ADA?) } & Age & 0.040 & 0.876 \\
\hline & & Gender & 0.003 & 0.091 \\
\hline & & Clinical Experience & 0.247 & 1.000 \\
\hline
\end{tabular}

\section{DISCUSSION}

One topic of major interest in contemporary dentistry is the biological complications that are associated with dental implant therapy. These complications are usually inflammatory in nature coupled with bacterial challenges [10 - 12]. There are two clinical varieties that are commonly identified; periimplant mucositis and peri-implantitis. Both diseases have an inflammatory lesion in the peri-implant mucosa, but the latter is characterized by progressive bone loss too [13]. Furthermore, many features are common between periimplantitis and chronic adult periodontitis. This makes it important for dental implant practitioners to have knowledge about peri-implantitis in order to properly identify and manage these implant related complications.

This study population consisted of an almost similar proportion of male and female dentists which is similar to the study conducted by Tripathi et al. . Most of the participants included in this study had attended an implant training course $(51.2 \%)$ and most of them had received this training either in an academic setting $(25.4 \%)$ or from private course providers (26.1\%). Only $21.5 \%$ of the participants strongly agree that the training provided was optimum, while the majority $(51.2 \%)$ agree that the training was optimum. Studies have reported that a combination of clinical, didactic and simulation training is more effective in producing confidence and necessary skills among pre-doctoral students [14]. It is yet to be conclusively determined if the type of setting where training was received has any effect on knowledge. In our present study, the difference in knowledge was statistically significant among different training settings with respect to age, gender and clinical experience. In a similar study by Kadkhodazadeh et al. (2017) [9], majority of the participants had received dental implant training (97\%) from an academic setting $(61.8 \%)$ and agreed that they received optimum training $(44.7 \%)$.

The majority of the participants in our study (67.3\%), believed that a special instrument is required for probing in peri-implantitis, with the most participant's choosing a plastic probe $(25.2 \%)$ followed by a stainless-steel probe $(23.7 \%)$ and most $(37.2 \%)$ believed that scaling of an implant surface must be carried out with a plastic curette. Prataptharajan and Suresh (2012) [6] recommend using a rigid plastic probe to measure probing death. It was earlier believed that stainless steel probes may further damage the already frail periodontal tissues in an infected implant site, but the Consensus Report of the Sixth European Workshop on Periodontology (Lindhe et al. 2016) [13] clarified that probing using a conventional stainless-steel probe with a light force of $0.25 \mathrm{~N}$ does not damage either the mucosa or the implant. In addition, Farkhavar et al. (2012) [15] conducted an in-vitro study to test the effect of probes and scalers made of both metal and plastic on implant abutment surfaces. The study found that plastic probes produced surface roughness of the implant while metal probes did not. Other studies have shown that out of different oral hygiene instrumentations and methods like hand scaling with metal and plastic scalers, ultrasonic scaling with metal tips, weekly rubber cup polishing, air polishing, and daily brushing, rubber cup polishing with daily brushing produced the smoothest implant surfaces while plastic scalers performed better than metal scalers [16 - 18]. Some studies also recommend carbon fiber curettes and titanium curettes [7, 19, 20].

Most participants in our study could differentiate between a normal and abnormal tissue $(79.3 \%)$, between peri-implant mucositis and peri-implantitis $(54.8 \%)$, between the initiating mechanisms of peri-implantitis and periodontitis $(52.7 \%)$, and between the progression times in periodontitis and periimplantitis (40.9\%). This displays that more than half of the participants can identify peri-implantitis from other similar infections. This is important as the first step in managing any disease is proper diagnosis. There are several parameters that are used to define the onset, extent and severity of periimplantitis that help in its diagnosis. These include radiographic bone loss, probing depth, bleeding on probing, and suppuration. Mombilli et al. (2012) [21] defined the typical bone loss around implants to be a strictly demarcated, craterlike defect without any notable signs of implant mobility. Since 
mobility denotes complete failure of the implant, the American Academy of Periodontology does not regard mobility as a diagnostic parameter and recommends the removal of the failed implant. There is no bone loss in peri-implant mucositis, which is the most distinguishing factor of peri-implantitis and periimplant mucositis.

Lastly, there have been reports on the use of different kinds of antibiotics in conjunction with non-surgical and surgical mechanical debridement for the treatment of both chronic and aggressive periodontitis such as tetracyclines, doxycycline, penicillin (amoxicillin), metronidazole, macrolides (spiramycin, erythromycin, azithromycin), clindamycin and ciprofloxacin. A combination of amoxicillin and metronidazole is the most commonly reported combination therapy for the treatment of periodontitis [21, 22]. These aforementioned antibiotics have also been reported to be used for the management of peri-implantitis with the addition of ornidazole and azithromycin [23 - 26]. However, the significance of adjunctive antibiotic therapy in the treatment of peri-implantitis is controversial [24] and there is a lack of adequate research on the effectiveness and clinical advantages of the use of systemic antibiotics as part of the standard mode of peri-implantitis management $[27,28]$. This precludes the need to conduct more randomized clinical trials to conclusively establish whether antibiotics help as adjunctive management strategies to clinical debridement. In our study, most participants $(76 \%)$ chose the amoxicillin-metronidazole combination therapy as the most effective method to treat peri-implantitis, which is in line with reported literature [23, 24].

This study provides some important insights into the knowledge of dentists in Saudi Arabia regarding the management of peri-implant diseases. The surveyed participants seem to possess adequate knowledge in some questions and less than adequate knowledge in some other questions. To the best of the author's knowledge, this is the first multi-centre study done from the region involving a large sample and adds valuable information to literature that can be used by policy makers, course creators and academics teaching dental implant therapy in Saudi Arabia. As with all crosssectional studies, response bias could be a limitation of this study.

\section{CONCLUSION}

This study concludes by suggesting that most of the participants have adequate knowledge about peri-implant soft tissue assessment, mechanism of periodontitis and periimplantitis, its initiation and progression, along with its management. Most of the participants found the training courses on peri-implantitis to be efficient. It is recommended to conduct more courses and studies that would aim at understanding the pathogenesis, etiology, diagnosis, and treatment of peri-implant diseases so as to increase awareness among dentists.

\section{ETHICS APPROVAL AND CONSENT TO PARTICIPATE}

The ethical clearance for the study was obtained from the ethical committee of the College of Dentistry, Prince Sattam
Bin Abdulaziz University Alkharj, with reference number (IRB/PSAU2020017).

\section{HUMAN AND ANIMAL RIGHTS}

No animals were used in this research. All human research procedures followed were in full accordance with the ethical standards of the committee responsible for human experimentation (institutional and national), and with the World Medical Association Declaration of Helsinki of 1975, as revised in 2008 .

\section{CONSENT FOR PUBLICATION}

A written consent to publish this information was obtained from all the participants for publication of this study.

\section{STANDARDS OF REPORTING}

STROBE guidelines were followed in this study.

\section{AVAILABILITY OF DATA AND MATERIALS}

The data that supports the findings of this study are available at reasonable request to the corresponding author.

\section{FUNDING}

None.

\section{CONFLICT OF INTEREST}

The authors declare no conflict of interest, financial or otherwise.

\section{ACKNOWLEDGEMENTS}

The authors are thankful to the Deanship of Scientific Research, Prince Sattam Bin Abdulaziz University, Alkharj, Saudi Arabia, for supporting this study.

\section{REFERENCES}

[1] Khammissa RAG, Feller L, Meyerov R, Lemmer J. Peri-implant mucositis and peri-implantitis: Clinical and histopathological characteristics and treatment. SADJ 2012; 67(3): 122-, 124-126. [PMID: 23198360]

[2] Afrashtehfar KI, Esfandiari S. Five things to know about peri-implant mucositis and peri-implantitis. J N J Dent Assoc 2017; 88(1): 24-5. [PMID: 30399224]

[3] Heitz-Mayfield LJ. Peri-implant diseases: Diagnosis and risk indicators. J Clin Periodontol 2008; 35(8)(Suppl.): 292-304. [http://dx.doi.org/10.1111/j.1600-051X.2008.01275.x] [PMID: 18724857]

[4] Afrashtehfar KI, Brägger U, Hicklin SP. Reliability of interproximal bone height measurements in bone and tissue-level implants: A methodological study for improved calibration purposes. Int J Oral Maxillofac Implants 2020; 35(2): 289-96.

[http://dx.doi.org/10.11607/jomi.7763] [PMID: 32142565]

[5] Afrashtehfar KI, Afrashtehfar CD. Lack of association between overload and peri-implant tissue loss in healthy conditions. Evid Based Dent 2016; 17(3): 92-3.

[http://dx.doi.org/10.1038/sj.ebd.6401193] [PMID: 27767107]

[6] Prathapachandran J, Suresh N. Management of peri-implantitis. Dent Res J (Isfahan) 2012; 9(5): 516-21.

[http://dx.doi.org/10.4103/1735-3327.104867] [PMID: 23559913]

[7] Figuero E, Graziani F, Sanz I, Herrera D, Sanz M. Management of peri-implant mucositis and peri-implantitis. Periodontol 2000 2014; 66(1): 255-73.

[http://dx.doi.org/10.1111/prd.12049] [PMID: 25123773]

[8] Matarasso S, Quaremba G, Coraggio F, Vaia E, Cafiero C, Lang NP. Maintenance of implants: an in vitro study of titanium implant surface 
modifications subsequent to the application of different prophylaxis procedures. Clin Oral Implants Res 1996; 7(1): 64-72.

[http://dx.doi.org/10.1034/j.1600-0501.1996.070108.x] [PMID: 9002824]

[9] Kadkhodazadeh M, Hosseinpour S, Kermani M, Amid R. Knowledge and attitude of iranian dentists towards peri-implant diseases. J Periodontal Implant Dent 2017; 9(1): 12-7.

[http://dx.doi.org/10.15171/jpid.2017.003]

[10] Lang NP, Berglundh T. Working Group 4 of Seventh European Workshop on Periodontology. Peri-implant diseases: Where are we now? Consensus of the Seventh European Workshop on Periodontology. J Clin Periodontol 2011; 38(11): 178-81. [http://dx.doi.org/10.1111/j.1600-051X.2010.01674.x] [PMID: 21323713]

[11] Sanz M, Chapple IL. Working Group 4 of the VIII European Workshop on Periodontology. Clinical research on peri-implant diseases: Consensus report of Working Group 4. J Clin Periodontol 2012; 39(12)(Suppl. 12): 202-6.

[http://dx.doi.org/10.1111/j.1600-051X.2011.01837.x] [PMID: 22533957]

[12] Jepsen S, Berglundh T, Genco R, et al. Primary prevention of periimplantitis: Managing peri-implant mucositis. J Clin Periodontol 2015; 42(16)(Suppl. 16): S152-7.

[http://dx.doi.org/10.1111/jcpe.12369] [PMID: 25626479]

[13] Lindhe J, Meyle J. Peri-implant diseases: Consensus report of the Sixth European Workshop on Periodontology. J Clin Periodontol 2008; 35(8)(Suppl.): 282-5.

[http://dx.doi.org/10.1111/j.1600-051X.2008.01283.x] [PMID: 18724855]

[14] Prasad S, Bansal N. Predoctoral dental students perceptions of dental implant training: Effect of preclinical simulation and clinical experience. J Dent Educ 2017; 81(4): 395-403.

[http://dx.doi.org/10.21815/JDE.016.001] [PMID: 28365603]

[15] Fakhravar B, Khocht A, Jefferies SR, Suzuki JB. Probing and scaling instrumentation on implant abutment surfaces: An in vitro study. Implant Dent 2012; 21(4): 311-6.

[http://dx.doi.org/10.1097/ID.0b013e3182588822] [PMID: 22814556]

[16] Homiak AW, Cook PA, DeBoer J. Effect of hygiene instrumentation on titanium abutments: A scanning electron microscopy study. J Prosthet Dent 1992; 67(3): 364-9.

[http://dx.doi.org/10.1016/0022-3913(92)90248-9] [PMID: 1324308]

[17] Rapley JW, Swan RH, Hallmon WW, Mills MP. The surface characteristics produced by various oral hygiene instruments and materials on titanium implant abutments. Int J Oral Maxillofac Implants 1990; 5(1): 47-52. [PMID: 2202669]

[18] Speelman JA, Collaert B, Klinge B. Evaluation of different methods to clean titanium abutments. A scanning electron microscopic study. Clin
Oral Implants Res 1992; 3(3): 120-7.

[http://dx.doi.org/10.1034/j.1600-0501.1992.030304.x]

[PMID:

1290792]

[19] Heitz-Mayfield LJA, Salvi GE, Botticelli D, Mombelli A, Faddy M, Lang NP. Anti-infective treatment of peri-implant mucositis: A randomised controlled clinical trial. Clin Oral Implants Res 2011; 22(3): 237-41.

[http://dx.doi.org/10.1111/j.1600-0501.2010.02078.x]

[PMID: 21251076]

[20] Schär D, Ramseier CA, Eick S, Arweiler NB, Sculean A, Salvi GE. Anti-infective therapy of peri-implantitis with adjunctive local drug delivery or photodynamic therapy: Six-month outcomes of a prospective randomized clinical trial. Clin Oral Implants Res 2013; 24(1): 104-10.

[http://dx.doi.org/10.1111/j.1600-0501.2012.02494.x] [PMID: 22568744]

[21] Mombelli A, Müller N, Cionca N. The epidemiology of periimplantitis. Clin Oral Implants Res 2012; 23(6)(Suppl. 6): 67-76. [http://dx.doi.org/10.1111/j.1600-0501.2012.02541.x] 23062130]

[22] Heitz-Mayfield LJA. Systemic antibiotics in periodontal therapy. Aust Dent J 2009; 54(Suppl. 1): S96-S101.

[http://dx.doi.org/10.1111/j.1834-7819.2009.01147.x] [PMID 19737272]

[23] Heitz-Mayfield LJA, Lang NP. Antimicrobial treatment of periimplant diseases. Int J Oral Maxillofac Implants 2004; 19(Suppl.): 128-39.

[PMID: 15635953]

[24] Jan van winkelhoff A. Antibiotics in the treatment of peri-implantitis Eur J Oral Implantology 2012; 5(Suppl.): S43-50.

[25] Javed F, Alghamdi AST, Ahmed A, Mikami T, Ahmed HB, Tenenbaum HC. Clinical efficacy of antibiotics in the treatment of peri-implantitis. Int Dent J 2013; 63(4): 169-76. [http://dx.doi.org/10.1111/idj.12034] [PMID: 23879251]

[26] Mombelli A, Lang NP. Antimicrobial treatment of peri-implant infections. Clin Oral Implants Res 1992; 3(4): 162-8. [http://dx.doi.org/10.1034/j.1600-0501.1992.030402.x] 1298430]

[27] Tripathi R, Vasudevan S, Palle AR, Gedela RK, Punj A, Vaishnavi V. Awareness and management of peri-implantitis and peri-mucositis among private dental Practitioners in Hyderabad - A cross-sectional study. J Indian Soc Periodontol 2020; 24(5): 461-6.

[http://dx.doi.org/10.4103/jisp.jisp 301 19] [PMID: 33144775]

[28] Di Murro B, Pranno N, Raco A, Pistilli R, Pompa G, Papi P. Knowledge and attitude towards retrograde peri-implantitis among Italian implantologists: A cross sectional survey. Int J Environ Res Public Health 2020; 17(22): 8356. [http://dx.doi.org/10.3390/ijerph17228356] [PMID: 33198070]

(C) 2021 Alqahtani et al.

This is an open access article distributed under the terms of the Creative Commons Attribution 4.0 International Public License (CC-BY 4.0), a copy of which is available at: https://creativecommons.org/licenses/by/4.0/legalcode. This license permits unrestricted use, distribution, and reproduction in any medium, provided the original author and source are credited. 